\title{
Akses Masyarakat Adat Terhadap Tanah Ulayat: Studi Kasus pada Masyarakat Adat Minangkabau
}

\author{
Al Hafidh ${ }^{1}$, Krisdyatmiko ${ }^{2}$
}

\begin{abstract}
Abstrak
Artikel ini mengeksplorasi bagaimana masyarakat Minangkabau di Nagari Bawan mengakses tanah adat mereka setelah reformasi politik Indonesia pada tahun 1998 berlangsung. Untuk mendapatkan pemahaman lebih lanjut tentang topik ini, metode studi kasus digunakan untuk memahami masalah yang lebih kompleks dan terperinci secara komprehensif. Studi ini menemukan bahwa akses masyarakat ke tanah ulayat telah menghadapi beberapa tantangan yang berasal dari faktor internal dan eksternal. Faktor-faktor internal berasal dari sistem adat yang berlaku di Nagari Bawan, di mana dominasi para pemimpin adat dalam pengambilan keputusan mengakibatkan akses lebih mengarah pada petinggi-petinggi adat, sementara faktor-faktor eksternal mengenai kerangka kerja peraturan formal menjadi tidak kontekstual dengan kondisi saat ini dan belum mampu mengakomodasi implementasi hukum adat yang selaras dengan kebutuhan masyarakat; terutama pembentukan instrumen hukum yang terkait erat dengan perlindungan hukum bagi pemegang hak ulayat.
\end{abstract}

Kata kunci: agraria, minangkabau, nagari bawan, reformasi, tanah ulayat

\begin{abstract}
This article explores how the Bawan Nagari community access their customary land after the Indonesian political reform in 1998, leading to grant social rights' all citizens. To gain further understanding of this topic, the case study method is employed to grasp further complex and detailed issues comprehensively. This study found that community access to customary land faces several challenges stemming from internal and external factors. Internal factors stem from the indegenious tradition system adopted at Nagari Bawan, where the greater dominance to customary leaders in decision making has led to abuse of power. While external factors concerning the formal regulatory framework is suffering from in-contextualized with the current conditions and has not able in accommodating the implementation of customary law that relevant to the current situation; especially the establishment of legal instrument that closely related to the legal protection of customary rights holders.
\end{abstract}

Key words: agraria, customary land, minangkabau, nagari bawan, reform

\section{Pendahuluan}

Berakhirnya kekuasaan rezim Orde Baru pada tahun 1998 telah membuka peluang bagi demokratisasi yang lebih luas sekaligus mengakhiri dua dekade sistem pemerintahan yang sentralistik. Sehubungan dengan ini, Undang-Undang Nomor 22 Tahun 1999 tentang otonomi daerah seluas-seluasnya diimplementasikan. Dalam konteks Sumatera Barat, undang-undang ini mensti-mulasi bagi perumusan kerangka kerja yang diorientasikan untuk mereaktualisasikan entitas adat yang telah memudar dalam periode pemerintahan Orde Baru. Kerangka kerja tersebut dikenal dengan tagline "babaliak ka nagari" yang bermakna kembali pada tatanan komunitas lokal-adat Minang-kabau (nagari).

Setelah berjalannya "babaliak ka nagari", Masyarakat Sumatera Barat mengenal kembali nagari sebagai wilayah komunitas lokal adat Minangkabau di Sumatera Barat dan berdaulat sebagai wilayah pemerintahan terendah dalam sistem pemerintahan di Indonesia. Pertanyaan yang kemudian muncul apakah masyarakat nagari benar-benar telah mendapatkan kembali akses terhadap tanah ulayat mereka yang terlanjur berpindahtangan ke negara, atau pihak swasta, serta bagaimana akses terhadap tanah ulayat yang kini terlanjur berpindah tangan kepada pihak lain.

\footnotetext{
${ }^{1}$ Sekretariat Daerah Kabupaten Agam, Sumatera Barat (email korespondensi: 41.hafidh@gmail.com) ${ }^{2}$ Departemen Pembangunan Sosial dan Kesejahteraan, Universitas Gadjah Mada (email: krisdyatmiko@ yahoo.com)
} 
Terhadap latar belakang ini, beberapa rumusan masalah diajukan, antara lain: bagaimanakah penguasaan atas tanah ulayat Nagari Bawan; bagaimanakah pemanfaatan tanah ulayat Nagari Bawan; bagaimana mekanisme akses masyarakat Nagari Bawan terhadap tanah ulayat Nagari Bawan, dan; apa saja tantangan yang dihadapi masyarakat Nagari Bawan dalam akses terhadap tanah ulayat Nagari Bawan.

Belum banyak studi yang secara spesifik mengkaji kasus yang diangkat dalam artikel ini. Namun demikian, beberapa penelitian terdahulu yang memiliki tema serupa dapat menjadi kerangka acuan penulis dalam melakukan penelitian lebih lanjut. Beberapa penelitian tersebut antara lain, Sari (2010) yang mengeksplorasi keberadaan tanah ulayat dalam masyarakat Minangkabau, selanjutnya Astuti dkk (2009) yang mene-mukan terdapat transformasi pemerin-tahan desa ke nagari merupakan perubahan sosial yang didorong oleh kebijakan negara (faktor eksternal) dan gerakan sosial (internal). Penelitian selanjutnya, yakni Nasir (2013), yang menyatakan bahwa keberlanjutan penguasa-an oleh negara terhadap tanah ulayat masyarakat Kampung Naga melalui pengelolaan hutan adat dikelola oleh sektor privat dan terakhir Melati (2016), menun-jukan bahwa praktik hak ulayat laut masih berjalan pada tatanan masyarakat Biak. Hal itu tidak terlepas dari akomodasi dari peraturan perundangundangan dan pelaksanaannya di daerah yang melindungi hak ulayat laut.

\section{Kerangka Teori \\ Teori Akses}

Berdasarkan pada Ribot dan Peluso (2003) dalam karyanya "A Theory of Access", akses didefinisikan sebagai kemampuan untuk memperoleh keuntungan-keuntungan dari "sesuatu", yang bisa saja merupakan hartabenda, orang, lembaga dan hal-hal lain yang dapat dimiliki. Kemampuan yang dimaksud lebih mengacu pada "kekuasaan" bukan "kepemilikan". Akses dalam pemikiran Ribot dan Peluso, menyangkut tentang siapa yang sebenarnya memperoleh keuntungan dari sumber daya dan bagaimana mereka mendapatkan keuntungan tersebut terlepas dari apakah mereka yang memiliki sumber daya tersebut atau tidak.

Kekuasaan terdiri dari jalinan beberapa unsur, seperti materi, budaya dan ekonomi politik yang membentuk rangkaian dan jaringan kekuasaan (Muur, 2018; Lanz, Gerber, \& Haller, 2018). Orang atau institusi yang berbeda akan menggambarkan rangkai-an kekuasaan yang berbeda, kemudian membentuk jaringan kekuasaan yang berbeda juga. Penggunaan istilah "jalinan", "rangkaian" dan "jaringan" menunjukan bahwa ada mekanisme yang melibatkan aspek struktural dan relasional yang berperan dalam pembentukan kekuasaan (Lombard \& Rakodi, 2016; Berenschot, 2018).

\section{Dasar Hukum Pengakuan Tanah Ulayat}

Beberapa peraturan perundang-undangan yang menjadi pedoman dalam permasalahan akses terhadap tanah ulayat yang masih berlaku adalah sebagai berikut:

a. Undang-Undang Dasar Tahun 1945 Pasal 18B ayat 2 menyatakan negara mengakui dan menghormati kesatuan-kesatuan masyarakat hukum adat beserta hak-hak tradisionalnya sepanjang masih hidup dan sesuai dengan perkembangan masyarakat dan prinsip Negara Kesatuan Republik Indonesia.

b. Undang-Undang Nomor 5 Tahun 1960 Tentang Peraturan Dasar Pokok-Pokok Agraria memberikan ruang untuk diperlakukannya hukum adat dalam mengatur bumi, air dan ruang angkasa sepanjang tidak bertentangan dengan kepentingan nasional. Peraturan Menteri Agraria/Kepala BPN.

c. Nomor 5 Tahun 1999 Tentang Pedoman Penyelesaian Masalah Tanah Ulayat Masyarakat Hukum Adat. Peraturan ini mengamanatkan prosedur teknis dalam penyelesaian urusan-urusan menyangkut tanah ulayat.

d. Keputusan Mahkamah Konstitusi Nomor 35/PUU-X/2012. Keputusan ini merupa-kan hasil dari gugatan terhadap Undang-Undang Kehutanan oleh 3 aliansi masyarakat hukum adat. Keputusan ini menyatakan bahwa hutan adat bukan merupakan hutan negara seperti yang diatur dalam undang-undang kehutanan yang menyebutkan hutan adat adalah hutan negara yang terletak di wilayah masyarakat hukum adat.

e. Undang-Undang Nomor 6 Tahun 2014 tentang Desa menyatakan bahwa Desa diberikan kewenangan hak asal usul untuk mengurus kepentingan masyarakatnya. 
Kewenangan hak asal usul membuat desa dapat mengatur kepentingan masyarakat berdasarkan historis dan identitas budaya termasuk di dalamnya tanah ulayat.

f. Peraturan Menteri Desa, Pembangunan Daerah Tertinggal Dan Transmigrasi Nomor 1 Tahun 2015 Tentang Pedoman Kewenangan Berdasarkan Hak Asal Usul dan Kewenangan Lokal Berskala Desa. Pengelolaan tanah ulayat merupakan salah satu ruang lingkup kewenangan hak asal usul desa.

Tanah Ulayat dan Hak Ulayat Masyarakat Nagari

Nagari dapat dipahami sebagai sebuah terminologi yang digunakan untuk menjelaskan suatu wilayah yang ditempati komunitas adat Minangkabau dengan ikatan genealogis secara matrilineal yang memiliki aturan sendiri untuk mengatur tata kehidupan anggota-anggotanya dengan serangkaian tatanan sosial budaya tertentu. Nagari merupakan wilayah otonom, yang disebut sebagai sebagai "republik mini" dengan pemerintahan berbasis masyarakat (self-governing community) yang dipimpin secara kolektif oleh perwakilan masing-masing kelompok yang berada di dalamnya dan memiliki teritorial yang jelas (Manan, 1995; Eko, 2005).

Struktur sosial masyarakat nagari ditata menurut prinsip matrilineal tetapi untuk urusan kepemimpinan memakai prinsip patriarki (lakilaki sebagai pemimpin). Kelompok-kelompok masyarakat dalam nagari dikelompokan berdasarkan sistem kekerabatan menurut garis keturunan ibu, tetapi pemimpin dari masing-masing kelom-pok merupakan seorang laki-laki yang disebut mamak. Masing-masing nagari mempunyai istilah yang berbeda dalam menyebutkan kelompok-kelompok masyarakatnya, tetapi secara umum kelompokkelompok masyarakat nagari terdiri dari suku, kaum dan paruik. Sebuah suku terdiri dari beberapa kaum, sebuah kaum terdiri dari beberapa paruik dan sebuah paruik terdiri dari beberapa keluarga inti yang berkerabat dalam satu garis keturunan secara matrilineal. Masing-masing kelompok masyarakat ini dipimpin oleh seorang mamak dengan sebutan tunganai (pemimpin paruik), panghulu kaum/ andiko (pemimpin kaum) dan panghulu suku/ pucuak (pemimpin suku), mereka merupakan manajer di unit kerja masing-masing yang berhak mengatur tata kehidupan anggotanya (kemenakan) (Manan, 1995).
Wilayah nagari biasanya terdiri dari "hutan rendah" dan "hutan tinggi". Hutan rendah mencakip wilayah yang telah diolah berupa wilayah pemukiman, sawah, ladang dan lain-lain. "Hutan tinggi" merupakan rimba belantara yang belum diolah, disebut sebagai tanah ulayat nagari, yang berfungsi sebagai lahan cadangan apabila hutan rendah tidak sanggup lagi mengakomodasi kebutuhan masyarakat. Wilayah "hutan tinggi" disebut sebagai "tanah ulayat nagari", yang berarti status hak ulayatnya berada pada masyarakat dalam skala nagari. Sedangkan hutan rendah sering disebut "tanah ulayat suku" dan "tanah ulayat kaum" yang akan terbagi status hak ulayatnya pada masyarakat dalam skala suku, kaum, paruik (harato pusako) dan keluarga (harato pancaharian). Dalam hukum adat Minangkabau, tanah ulayat nagari dimiliki secara komunal oleh semua masyarakat nagari dan tidak akan berpindah tangan, kecuali apabila sudah digarap dan tempati oleh kelompok masyarakat dari suku tertentu akan berubah statusnya menjadi tanah ulayat suku dengan mekanisme yang ada dalam hukum adat (Evers, 1975; F dan K Benda-Beckman, 1994; dan Manan, 1995). Nasroen (1971) menegaskan bahwa semua wilayah nagari di Minangkabau dan semua yang terkandung didalamnya adalah tanah ulayat yang dikendalikan oleh panghulu.

\section{Metode}

Penelitian ini berupaya memahami dan mengkaji gejala sosial tentang pergolakan penguasaan dan pemanfaatan tanah ulayat Nagari Bawan secara mendalam. Secara lebih spesifik, penelitian ini diarahkan untuk menjawab permasalahan terkait akses masyarakat Nagari Bawan terhadap tanah ulayat Nagari Bawan. Berdasarkan pertimbangan tersebut, penelitian ini menggunakan metode kualitatif. Menurut Sugiyono (2010) dan Moleong (2013), metode kualitatif menjadi relevan digunakan untuk meneliti fokus permasalahan yang mempunyai ruang lingkup terperinci yang dikaji secara mendalam, utuh dan menyeluruh (holistik). Sementara pendekatan yang digunakan dalam penelitian ini adalah studi kasus, yaitu suatu pendekatan penelitian kualitatif dengan cara menyelidiki kejadian dalam konteks dunia nyata secara empiris.

Penelitian ini dilakukan di lokasi terjadinya pergolakan penguasaan dan pemanfaatan lahan antara masyarakat nagari dengan PT. Argo 
Masang Perkasa (AMP) Plantation yang berkaitan dengan tanah ulayat, yaitu Nagari Bawan yang terletak di Kecamatan Ampek Nagari Kabupaten Agam Provinsi Sumatera Barat. Proses penelitian ini dilakukan dalam waktu 7 bulan (September 2017- April 2018) sejak persiapan yang meliputi observasi pra-penelitian, hingga penyusunan laporan penelitian.

\section{Metode Pengumpulan Data}

Pengumpulan data dengan cara telaah dokumen dilakukan dengan cara melakukan tinjauan terhadap dokumen-dokumen yang terkait dengan informasi tentang permasala-han penelitian. Dokumen-dokumen yang menjadi bahan pertimbangan adalah dokumen-dokumen yang berisi tentang informasi mengenai tanah ulayat di Nagari Bawan. Hasil telaah dokumen yang dilakukan memberikan ilustrasi bahwa telah ada upaya yang dilakukan pemerintah daerah untuk mengakomodasi pengakuaan hak-hak masyarakat adat, termasuk mengenai tanah ulayat. Informasi lain yang didapat dari telaah dokumen dalam penelitian ini adalah mengenai proses dan legalitas penguasaan dan pemanfaatan tanah ulayat Nagari Bawan oleh Masyarakat Nagari Bawan di tengah keberadaan PT. AMP Plantation.

Wawancara dilakukan kepada informan dengan cara menentukan informan utama terlebih dahulu dengan menggunakan teknik purposive sampling, yaitu pemilihan informan berdasarkan intuisi peneliti dengan mempertimbangkan siapa yang menguasai informasi. Setelah informan utama dipilih, maka penentuan informan pendukung dilakukan dengan teknik snowball, yaitu bergulir sesuai keterkaitan informasi yang didapat dari informan sebelumnya (Sugiyono, 2010; dan Moleong, 2013). Informan yang terlibat dalam penelitian ini digolongkan menjadi 3 golongan yang terdiri dari kalangan masyarakat adat Nagari Bawan, unsur pemerintahan dan pihak PT. AMP Plantation.

Stainback (Sugiyono, 2010) menjelas-kan bahwa dalam observasi, peneliti mengamati apa yang dikerjakan objek penelitian, mendengarkan apa yang mereka bicarakan dan berada dalam lingkungan mereka. Hal-hal yang diamati dalam penelitian ini adalah kondisi fisik tanah ulayat Nagari Bawan, aktivitas masyarakat dan interaksi sosial yang terjadi di area tanah ulayat, baik antara sesama masyarakat maupun dengan pihak lain. Hasil observasi yang dilakukan memberikan beberapa informasi mengenai bentuk pemanfaatan tanah ulayat, keleluasaan masyarakat dalam melaksanakan pemanfaatan tanah ulayat, gambaran tentang kalangan masyarakat yang terlibat dalam pemanfaatan tanah ulayat dan pola interaksi sosial yang muncul dalam pemanfaatan tanah ulayat serta pengecekan temuan pada metode pengum-pulan data lain mengenai deskripsi fisik tanah ulayat Nagari Bawan.

\section{Teknik Validasi Data}

Validitas data diuji dengan cara triangulasi. Wiersma (Sugiyono, 2010) menyebutkan, triangulasi adalah pengecekan silang data dari berbagai sumber dan berbagai waktu. Triangulasi yang dilakukan adalah triangulasi sumber. Triangulasi sumber dilakukan dengan cara menguji kecocokan data dari berbagai sumber, baik dari satu metode pengumpulan data maupun berbagai metode pengumpulan data. Triangulasi pada penelitian ini secara operasional dilakukan pada data-data yang saling terkait, baik dari berbagai metode pengumpulannya maupun sumbernya. Data-data dari telaah dokumen, wawancara dan observasi saling diuji silang. Khusus untuk data-data hasil wawancara diuji silang dari berbagai informan berbeda dan juga dilakukan uji silang terhadap data-data dari masing-masing informan.

\section{Teknik Analisis Data}

Moleong (2013) menyebutkan ada beberapa metode untuk menganalisis data dalam penelitian kualitatif, salah satu metode yang sering digunakan adalah metode yang dikemukakan oleh Glaser dan Strauss yaitu metode perbandingan tetap (constant comparative method) dengan langkah-langkah yang dimulai dari Reduksi Data, Kategorisasi, Sintesisasi dan Penyusunan Hipotesis Kerja.

Beberapa hipotesis kerja yang telah tersusun dikonfirmasikan lagi dengan fakta-fakta di lapangan melalui suatu proses pengecekan ulang ke lapangan penelitian. Hal ini dilakukan untuk memastikan beberapa argumen awal, yang merupakan sebuah dugaan sementara hasil penelitian, mempu-nyai makna yang tidak bergeser dari fakta-fakta yang terjadi. Setelah pengecekan dilakukan, maka proses selanjutnya adalah menyimpulkan beberapa hipotesis kerja menjadi suatu pernyataan yang tetap untuk 
menjawab pertanyaan-pertanyaan penelitian. Pernyataan-pernyataan tersebut dikembang-kan menjadi narasi-narasi untuk menyusun laporan penelitian.

\section{Hasil}

Deskripsi Umum Nagari Bawan dan Tanah Ulayat Nagari Bawan adalah sebuah nagari terletak di Kecamatan Ampek Nagari Kabupaten Agam Provinsi Sumatera Barat, sekaligus sebagai ibu kota kecamatan yang merupakan nagari paling luas di kecamatan tersebut dengan luas wilayah 170,43 km² (Kantor Wali Nagari Bawan, 2017). Nagari Bawan termasuk dalam kategori daerah dataran rendah dengan ketinggian permukaan berkisar antara 10-1.000 mdpl serta tekstur permukaan wilayah bergelombang dan berbukit-bukit. Lahan di Nagari Bawan sebagian besar digunakan untuk lahan perkebunan, penggunaan lahan lainnya adalah persawahan, permukiman dan masih ada lahan dalam bentuk hutan belukar. Kondisi geografis tersebut mempengaruhi mata pencaharian masyarakat Nagari Bawan, sebagian besar masyarakat Nagari Bawan melakukan kegiatan perekonomian di sektor perkebunan dan pertanian. Selain itu juga ada sebagai pedagang, buruh, peternak, pegawai negeri dan wiraswasta (BPS, 2017).

Bawan merupakan nagari yang cukup tua di Luhak Agam bagian wilayah barat. Menurut ranji, nenek moyang orang Bawan turun dari Matur terus ke Maninjau dan Sitalang. Setelah menelusuri lereng Bukit Talempong nenek moyang orang Bawan terdampar dan membuat kampung yang sekarang diberi nama Bawan yang berasal dari kata "baawan" (berawan), karena ketika mereka dalam perjalanan dan melihat daerah ini, yang terlihat adalah dataran rendah atau lembah yang dipenuhi kabut atau awan. Proses perkembangan Nagari Bawan sebagaimana konsep-konsep tentang nagari yang telah diketahui secara umum dalam tatanan adat Minangkabau, yaitu dari wilayah yang baru ditemukan dan diolah atau disebut taratak ${ }^{3}$, kemudian menjadi $d u s u n^{4}$, selanjutnya menjadi

\footnotetext{
${ }^{3}$ Taratak adalah wilayah yang baru dibuka sebagai tempat bercocok tanam yang belum dijadikan pemukiman.

${ }^{4}$ Dusun merupakan bentuk yang lebih kompleks dari taratak yang telah dijadikan pemukiman dan terdiri dari beberapa keluarga.
}

$k t_{0}{ }^{5}$, dan akhirnya menjadi Nagari Bawan seperti saat ini.

Nagari Bawan menganut aliran dari prinsip sistem adat Lareh Koto Piliang yang memiliki prinsip "manitiak dari ateh (menetes dari atas)" yang bermakna semua keputusan berdasarkan titah pemimpin adat, sebagaimana disebut juga dengan adaik barajo-rajo (adat mempunyai pemimpin), batinggi-barandah (ada posisi di atas dan di bawah), badahulubakudian (ada yang di depan dan ada yang di belakang), dengan struktur adat yang bertingkat dan menuntut kearifan serta kebijaksanaan pemimpin adat dalam menanggapi kepentingan kaumnya.

Sementara lembaga adat pada suatu nagari di Minangkabau sangat plural, namun dalam bahasan ini difokuskan pada 1 lembaga yang memiliki kekuasaan yang besar dan diakui juga secara formal terkait urusan tanah ulayat. Lembaga adat yang dimaksud adalah Kerapatan Adat Nagari (KAN). KAN menjadi bagian dari sistem pemerintahan nagari sebagai lembaga perwakilan permusyawara-tan dan pemufakatan adat tertinggi. Pandangan aturan formal di Sumatera Barat mengamanatkan KAN untuk menyelesaikan sengketa sako (kekayaan nonmateril, seperti gelar kehormatan) dan pusako (kekayaan materil yang diwarisi turun-temurun) menurut ketentuan sepanjang adat yang berlaku di nagari. Salah satu pusako yang terpenting dalam masyarakat Minangkabau adalah tanah ulayat.

Bagi adat Minangkabau, tanah tidak hanya sebagai sumber ekonomi, tetapi juga simbol eksistensi sebagai penentu hubungan kekerabatan. Masyarakat Minangkabau mengenal konsep tanah sebagai pusaka yang pantang berpindah ke tangan pihak lain sesuai ajaran adat "dijua indak dimakan bali, digadai indak dimakan sando". Falsafah tersebut menegaskan bahwa tanah ulayat itu tidak boleh dipindah tangankan pada orang lain, baik dalam bentuk jual maupun gadai, masyarakat boleh saja memanfaatkan, mengelola, mengolah dan menikmati hasil dari tanah ulayat sesuai ketentuan adat yang berlaku, namun hak kepemilikannya tetap milik komunal.

${ }^{5}$ Koto adalah wilayah yang telah memiliki sistem sosial, tetapi belum memiliki kelengkapan yang menjadi persyaratan untuk menjadi wilayah kesatuan masyarakat adat Minangkabau (nagari). 
Al Hafidh, Krisdyatmiko - Akses Masyarakat Adat Terhadap Tanah Ulayat: Studi Kasus pada Masyarakat Adat Minangkabau

Tanah ulayat nagari diartikan sebagai tanah ulayat beserta sumber daya alam yang ada di atas dan di dalamnya merupakan hak penguasaan oleh ninik mamak Kerapatan Adat Nagari (KAN) dan dimanfaatkan sebesarbesarnya untuk kepentingan masyarakat nagari, sedangkan pemerintahan nagari bertindak sebagai pihak yang mengatur untuk pemanfaatannya. Penguasaan tanah ulayat nagari oleh ninik mamak atau penghulupenghulu dalam nagari bergantung kepada sistem adat yang berlaku dalam nagari. Tanah ulayat nagari dalam sistem adat Lareh Koto Piliang dikuasai pemimpin adat tertinggi di nagari.

Prinsip adat menyebutkan bahwa tanah ulayat Nagari Bawan tidak dapat diperjualbelikan atau digadaikan, tetapi ada kondisi tertentu yang memberi celah untuk melanggar prinsip tersebut. Kondisi tersebut bisa untuk kepentingan pihak dalam (anak-kemenakan), maupun untuk pihak luar (pemerintah atau swasta). Kondisi untuk kepentingan anak-kemenakan adalah ketika tidak ada lagi solusi untuk menyelesaikan permasalahan yang menyangkut urusan terkait mayik tabujua dalam rumah (urusan pemakaman), gadih gadang alun balaki (urusan pernikahan), rumah gadang katirisan (urusan perumahan), mambangkik batang tarandam (urusan kehormatan). Khusus untuk pemanfaatan oleh pihak luar harus memenuhi ketentuan "Adat diisi limbago dituang" (Ada persyaratan yang harus dipenuhi oleh pihak yang akan menggunakan tanah ulayat) berdasarkan kesepakatan dengan penguasa tanah ulayat.

\section{Kebijakan Daerah terkait Tanah Ulayat Nagari Bawan}

Pemeintah Daerah, baik pada tingkat provinsi atau kabupaten/kota, selaku pihak yang diberi mandat sebagai daerah otonom berwenang mengakomodasi, mengurus dan mengatur kepentingan masyarakat di wilayahnya yang menyangkut dengan urusan pemerintahan yang dilimpahkan pemerintah pusat kepada pemerintah daerah, dengan catatan tidak bertentangan dengan aturan-aturan yang berada pada hirarki lebih tinggi sebagaimana yang tertuang dalam Undang-Undang Nomor 23 Tahun 2014 Tentang Pemerintah Daerah. Pemerintah Daerah Provinsi Sumatera Barat dan Kabupaten Agam telah menerbitkan beberapa aturan mengenai ketentuan yang menyangkut tanah ulayat. Aturan-aturan tersebut adalah sebagai berikut:

\section{a. Peraturan Daerah Provinsi Sumatera Barat Nomor 16 Tahun 2008 tentang Tanah Ulayat dan Pemanfaatannya \\ Azas pemanfaaatan tanah ulayat di} Sumatera Barat diatur sesuai filosofi adat Minangkabau yang berbunyi "jua indak makan bali, gadai indak makan sando", yang mempunyai makna tanah ulayat tidak bisa diperjualbelikan dan tidak bisa dijadikan agunan untuk penggadaian. Sasaran utama aturan ini supaya pemanfaatan tanah ulayat untuk kepentingan peningkatan kesejahteraan dan kemakmuran masyarakat adat. Apabila pihak lain ingin memanfaatkan tanah ulayat maka ada proses musyawarah dan mufakat yang harus dilalui yang berprinsip "adat diisi limbago dituang" (persyaratan adat dipenuhi). Jika tanah ulayat tidak lagi dimanfaatkan atau abis masa pemakaiannya maka tanah ulayat tersebut secara otomatis kembali dipegang oleh penguasanya secara hukum adat, atau diistilahkan dengan "kabau mati kubangan tingga" (status kepemilikan tanah ulayat tidak melekat pada pihak lain yang telah memanfaatkannya). Namun hak keperda-taan pihak lain yang berkaitan dengan tanah ulayat tetap menjadi perhatian.

Peraturan daerah ini menjelaskan bahwa investor dapat memanfaatkan tanah ulayat dengan mengikut sertakan penguasa dan pemilik tanah ulayat berdasarkan kesepakatan masyarakat adat yang bersangkutan sebagai pemegang saham, bagi hasil dan dengan cara lain dalam waktu yang telah ditentukan dalam perjanjian. Apabila perjanjian penyerahan hak penguasaan telah berakhir, maka status penguasaan tanah kembali ke ketentuan semula dan bisa diperpanjang dengan cara mengadakan mufakat dengan penguasa tanah ulayat.

\section{b. Peraturan Gubernur Sumatera Barat Nomor 21 Tahun 2012 Tentang Pedoman dan Tata Cara Pemanfaatan Tanah Ulayat untuk Penanaman Modal \\ Peraturan ini merupakan petunjuk pelaksanaan dari Peraturan Daerah Provinsi Sumatera Barat Nomor 16 Tahun 2008 Tentang Tanah Ulayat dan Pemanfaatannya. Regulasi ini juga mengatur kategori pemanfaatan tanah ulayat oleh penanam modal yang harus sesuai}


dengan ketentuan adat. Kegiatan penanaman modal harus disesuaikan dengan ketentuan adat pada masing-masing nagari. Kegiatan usaha yang bertentangan falsafah adat Minangkabau (adat basandi syarak, syarak basandi kitabullah), walaupun tidak menyalahi aturan formal, tentu tidak bisa dijalankan di atas tanah ulayat.

Proses "adat diisi, limbago dituang" dilakukan dalam bentuk ganti rugi, untuk tanah yang digunakan langsung untuk kegiatan penanaman modal, dan kompensasi untuk tanah yang terkena dampak kegiatan usaha. Setiap tanah ulayat dapat dimanfaatkan untuk penanaman modal berdasarkan kesepa-katan antara penanam modal dan pemilik atau penguasa tanah ulayat yang dilakukan dengan jalan musyawarah dan mufakat serta dituangkan dalam bentuk perjanjian kerjasama. Tahapan teknis yang harus dilalui penanam modal untuk memulai kegiatan usahanya di tanah ulayat hampir sama halnya dengan kegiatan usaha lainnya yang tidak memanfaatkan tanah ulayat, dimulai dari pengurusan perizinan usaha pada instansi yang terkait perizinan penanaman modal. Namun, dalam setiap tahapan tersebut melibatkan lembaga adat yang diberi kewenangan dalam mengurus urusan adat di nagari, yaitu Kerapatan Adat Nagari (KAN).

\section{c. Peraturan Daerah tentang Pemerintahan Nagari}

Ada dua peraturan daerah yang dirangkum dalam bahasan ini, yaitu Peraturan Daerah Provinsi Sumatera Barat Nomor 2 Tahun 2007 Tentang Pokok- Pokok Pemerintahan Nagari dan Peraturan Daerah Kabupaten Agam Nomor 12 Tahun 2007 Tentang Pemerintahan Nagari. Aturan-aturan ini menjelaskan bahwa ada beberapa urusan pemerintahan yang dilimpahkan dari pemerintah daerah kepada pemerintah nagari. Salah satu urusan yang dimaksud adalah kepengurusan tanah, sungai, hutan, laut dan lain-lain yang merupakan ulayat nagari. Hal-hal yang termasuk dalam ulayat nagari tersebut menjadi harta kekayaan nagari yang berada di bawah kewenangan pemerintah nagari berkordinasi dengan Kerapatan Adat Nagari (KAN) dan Badan Musyawarah (BAMUS) nagari. Aturan-aturan ini merupakan pedoman yang menjadi acuan untuk mengatur lebih lanjut mengenai pengelolaan harta kekayaan nagari, termasuk tanah ulayat. Tindak lanjut dari aturan-aturan ini dituangkan oleh pemerintah daerah tingkat kabupaten/kota dalam bentuk peraturan bupati terkait pengelolaan harta kekayaan nagari.

\section{d. Peraturan Bupati Agam Nomor 45 Tahun 2013 tentang Tata Cara Pengelolaan Kekayaan Nagari \\ Aturan ini menjelaskan bahwa tanah} ulayat termasuk ke dalam objek harta kekayaan nagari yang dapat dikelola oleh nagari. Pihak yang berwenang dalam pelaksanaan pengelolaan kekayaan nagari adalah pemerintah nagari. Regulasi ini memaparkan bahwa kekayaan nagari yang tidak dimanfaatkan nagari untuk kepentingan penyelenggaraan pemerintahan, pembangunan, pelayanan masya-rakat, dapat dimanfaatkan oleh pihak lain. Bentuk pemanfaatan oleh pihak lain meliputi sewa, pinjam pakai, kerjasama pemanfaatan, bangun guna serah dan bangun serah guna. Namun, bentuk pemanfaatan tersebut tidak dapat merubah status kepemilikan dari objek kekayaan nagari yang dimanfaatkan pihak lain. Pelepasan hak atas tanah ulayat hanya dapat dilakukan apabila dipergunakan untuk kepentingan umum, seperti pembangunan untuk hajat hidup masyarakat, misalnya jalan, sarana dan prasarana pengembangan masyarakat.

\section{Keberadaan PT. Agro Masang Perkasa (AMP) Plantation}

PT. AMP Plantation adalah anak usaha dari Wilmar Group yang bergerak di bidang agribisnis, tepatnya di sektor perkebunan kelapa sawit. Invansi PT. AMP Plantation sampai ke Nagari Bawan diakomodasi pada oleh Pemerintah Daerah Tingkat II AGAM pada tahun 1991, melalui mediasi yang dilakukan dengan cara mempertemukan pihak PT. AMP Plantation dengan niniak-mamak Nagari Bawan yang menghasilkan pernyataan menyambut dan mendukung rencana investasi yang dilakukan oleh PT. AMP Plantation di atas tanah ulayat Nagari Bawan dengan beberapa kesepakatan, antara lain pemenuhan syarat adat (adat diisi limbago dituang) dan persetujuan terkait 30\% persen dari total lahan dijadikan perkebunan plasma untuk masyarakat Nagari Bawan. Hasil pengukuran yang dilakukan oleh Badan Pertanahan Nasional Kantor Wilayah Provinsi Sumatera Barat menyatakan bahwa luas tanah ulayat Nagari Bawan yang terpakai oleh PT. AMP Plantation adalah 766, 51 hektar. Seluruh lahan 
Al Hafidh, Krisdyatmiko - Akses Masyarakat Adat Terhadap Tanah Ulayat: Studi Kasus pada Masyarakat Adat Minangkabau

tersebut telah dibuatkan sertifikat Hak Guna Usaha (HGU) Nomor 11 Tahun 2004 atas nama PT. AMP Plantation.

\section{Diskusi}

\section{Penguasaan dan Pemanfaatan Atas Tanah Ulayat Nagari Bawan}

Penguasaan tanah ulayat Nagari Bawan secara yuridis berada pada masyarakat adat Nagari Bawan secara komunal, yang diwakili oleh KAN Nagari bawan, atas dasar hak ulayat yang diakui dan dilindungi oleh peraturan perundangundangan dan pelaksa-naanya di Provinsi Sumatera Barat. Sedangkan penguasaan dari aspek fisik terbagi kepada PT. AMP Plantation yang menguasai $70 \%$ dari total luas tanah ulayat dan 30\% lagi berada pada penguasaan masyarakat hukum adat di Nagari Bawan. Penguasaan dari aspek fisik ini muncul karena dilandasi oleh proses hukum dalam bentuk perjanjian kesepakatan dan Hak Guna Usaha.

Pemanfaatan tanah ulayat Nagari Bawan umunya berbentuk perkebunan kelapa sawit melalui kerjasama kemitraan dengan cara pola Inti-Plasma. masyarakat adat Nagari Bawan secara komunal mendapatkan pemanfaatan dari tanah ulayat Nagari Bawan melalui penjualan hasil produksi perkebunan plasma. Distribusi penjualan hasil produksi perkebunan plasma dikelola oleh koperasi Bukit sandiang Tigo yang merupakan lembaga berbadan hukum yang dibentuk oleh ninik-mamak KAN Nagari Bawan.

\section{Mekanisme dan Tantangan Akses}

Deskripsi tentang penguasaan dan pemanfaatan tanah ulayat Nagari Bawan mengarahkan pemahaman bahwa Masyarakat Nagari Bawan secara komunal memiliki akses terhadap tanah ulayat mereka, dalam bentuk kesatuan masyarakat adat Nagari Bawan. Objek atau sumber daya yang dapat mereka akses adalah lahan dengan luas sekitar 226 hektar atau $30 \%$ dari total wilayah PT. AMP Plantation yang berada di tanah ulayat Nagari Bawan. Akses tersebut dimanfaatkan untuk upaya peningkatan kesejahteraan melalui kegiatan perkebunan kelapa sawit bermitra dengan pihak PT. AMP Plantation memakai pola kerjasama perkebunan inti-plasma.

Mekanisme yang membentuk akses masyarakat nagari terhadap tanah ulayat di Nagari Bawan dilandasi oleh legitimasi berupa kesepakatan antara pihak swasta, yaitu PT.
AMP Plantation dengan pihak masyarakat Nagari Bawan yang dimediasi dan difasilitasi oleh Pemerintah Daerah Kabupaten Agam. Kesepakatan ini dibuat untuk mengakomodasi kepentingan nasional dalam agenda peningkatan perekonomian negara melalui penye-diaan wilayah untuk investor di sektor perkebunan tanpa menyingkirkan hak masya-rakat adat atas wilayah adat di Nagari Bawan. Kesepakatan ini menjadi jalur untuk meme-nuhi ketentuan adat tentang pemanfaatan tanah ulayat.

Aspek struktural yang berperan membentuk akses ini adalah hubungan historis masyarakat Nagari Bawan dengan wilayah adat mereka memenuhi kategori yang disyaratkan oleh regulasi formal tentang pengakuan masyarakat hukum adat. Sedangkan aspek relasionalnya berkaitan dengan kemampuan masyarakat Nagari Bawan untuk mempengaruhi ide dan gagasan orang lain dalam suatu proses kesepakatan yang bermuara pada keberlangsungan akses. Aspek relasional ini berbentuk suatu interaksi sosial yang dilakukan masyarakat Nagari Bawan dengan pihakpihak lain seperti pemerintah dan PT. AMP Plantation melalui penyampaian kepentingan dalam musyawarah pada proses awal rencana pemanfaatan tanah ulayat yang menyebabkan masyarakat Nagari Bawan mendapatkan keuntungan dari penguasaan dan pemanfaatan terhadap tanah ulayat Nagari Bawan.

Pola penguasaan dan pemanfaatan yang dilakukan atas tanah ulayat Nagari Bawan yang telah dijelaskan pada bahasan sebelumnya, memberikan gambaran bahwa akses memang didapatkan oleh masyarakat secara komunal, tetapi akses cenderung lebih banyak mengalir pada segelintir masyarakat. Distribusi akses lebih condong menguntung-kan kalangan masyarakat yang memiliki kedudukan dalam struktur sosial masyarakat secara adat, karena mereka mempunyai dominasi dalam merumuskan suatu keputu-san yang berkaitan dengan distribusi akses tersebut. Faktor internal yang tampak adalah penggunaan kekuasaan untuk kepentingan pribadi atau golongan (abuse of power) yang dilakukan oleh ninik-mamak Nagari Bawan. Sistem adat Lareh Koto Piliang yang dianut dalam struktur masyarakat adat di Nagari Bawan memberikan kekuasaan sangat besar kepada pemuka adat dalam kelembagaan KAN untuk memutuskan segala sesuatu yang berkaitan dengan adat termasuk mengenai 
tanah ulayat. Hal ini makin menjaga abuse of power tetap berjalan karena tidak ada kekuatan lain untuk menentang apa yang telah diputuskan dan dilakukan oleh elit adat.

Petatah adat yang menyatakan "titiak dari ateh, kato surang nan gadang adolah kato nan bana (titah dari atas, kata seorang pemimpin adalah kata yang benar)", dimaknai sebagai kemutlakan keputusan yang diambil pemimpin adat adalah keputusan yang benar dan harus dipatuhi oleh masyarakat. Ini adalah abuse of power, kekuasaan yang seharusnya dijadikan sebagai alat untuk menyalurkan kepentingan masyarakat atau kaum mereka, malah dijadikan sebagai alat untuk memperlancar terwujudnya kepenti-ngan individu dan golongan.

Faktor lainnya adalah faktor eksternal yang berasal dari luar sistem sosial masyarakat Nagari Bawan. Faktor ini sangat erat kaitannya dengan faktor internal yang telah disebutkan sebelumnya. Faktor eksternal yang dimaksud adalah akomodasi yang diberikan aturan tertulis (formal) terhadap pemberlakuan hukum adat tanpa ada pembatasan dengan pertimbangan relevansi dan kontekstualisasi aturan adat tersebut dengan konteks kekinian yang ada pada kondisi masyarakat.

Selain gagasan yang disebutkan di atas, faktor eksternal lainnya juga berkaitan dengan aturan formal adalah ketidakpastian hukum terkait legalitas hak ulayat/komunal atas fisik tanah ulayat. Ketidakpastian hukum ini akan membuat kerumitan penyelesaian perkara yang melibatkan tanah ulayat dan masyarakat adat apabila terjadi permasalahan yang tidak bisa diselesaikan melalui ketentuan adat dan harus sampai pada proses hukum secara perdata atau pidana seperti yang telah diatur dalam Peraturan Daerah Provinsi Sumatera Barat Nomor 16 Tahun 2008 Tentang Tanah Ulayat dan Pemanfaatannya. Suatu instrumen hukum, semisal sertifikat tentu akan memberikan perlindungan hukum bagi subjek yang memiliki hak atas tanah tersebut.

\section{Kesimpulan}

Berdasarkan analisis yang telah dilakukan, dapat disimpulkan bahwa akses masyarakat Nagari Bawan terhadap tanah ulayat Nagari Bawan bergantung pada sektor swasta, yakni PT. AMP Plantation. Masyarakat yang diwakili niniak mamak menguasai tanah ulayat dan mendapatkan keuntungan dari pemanfaatan tanah ulayat melalui penjualan hasil produksi perkebunan plasma yang berada pada tanah ulayat Nagari Bawan. Akses masyarakat Nagari Bawan terhadap tanah ulayat Nagari Bawan saat ini dibayang-bayangi beberapa tantangan yang berpotensi menghambat keberlangsungan mekanisme akses yang berjalan. Tantangan akses yang dimaksud bersumber pada faktor internal masyarakat sendiri seperti penggunaan kekuasaan untuk kepentingan pribadi atau golongan (abuse of power) yang dilakukan oleh ninik-mamak Nagari Bawan dan faktor eksternal, yaitu ketidakpastian hukum terkait legalitas hak ulayat/komunal atas fisik tanah ulayat.

Sebagai rekomenasi, studi dengan pendekatan kuantitatif mengenai dampak dari pelaksanaan pengelolaan tanah ulayat terhadap tingkat kesejahteraan masyarakat adat sangat dibutuhkan untuk memberikan ukuran perubahan tingkat kesejahteraan masyarakat adat yang dilatarbelakangi pemanfaatan tanah ulayat. Pemerintah diharapkan mempertimbangkan kontekstualisasi dan relevansi regulasiregulasi pertanahan yang ada ber-dasarkan kondisi sosial terkini.

\section{Acknowledgement}

Artikel ini merupakan hasil penulisan ringkas tesis penulis yang telah diuji dan dinyatakan lulus untuk meraih gelas Master of Arts dari Departemen Pembangunan Sosial dan Kesejahteraan (PSdK), Fakultas Ilmu Sosial dan Ilmu Politik, Universitas Gadjah Mada pada tahun 2018.

\section{Referensi}

Aliansi Masyarakat Adat Nusantara (AMAN) (2017, 27 September). RUU Masyarakat Adat Akan Selesaikan Konflik, http:// www.aman.or.id/aman-ruu-masyarakatadat-akan-selesaikan-berbagai-konflik/ diakses pada 26 Oktober 2017.

AntaraNews Sumbar. (2013, 3 Juli). Masyarakat Bawan Hentikan Aktivitas PT AMP http:// www.antarasumbar.com/masyarakatbawan-hentikan-aktivitas-pt-amp / diakses pada 15 September 2017.

Astuti, N. B. dkk. (2009), Dilema Dalam Transformasi Desa ke Nagari (Studi Kasus di Kenagarian IV Koto Palembayan, Provinsi Sumatera Barat), Jurnal Transdisiplin Sosiologi, Komunikasi dan Ekologi Manusia, 3(2), pp. 153-172. 
Al Hafidh, Krisdyatmiko - Akses Masyarakat Adat Terhadap Tanah Ulayat: Studi Kasus pada Masyarakat Adat Minangkabau

Azrial, Y. (2008), Budaya Alam Minangkabau, Padang: Angkasa Raya

Benda-Beckman, F dan Benda-Beckman, K. (1994). Property, Politics, and Conflict: Ambon and Minangkabau Compared. Law \& Society Review, 28(3), pp. 589-608.

Berenschot, W. (2018). The political economy of clientelism: A comparative study of Indonesia's patronage democracy. Comparative Political Studies, 51(12).

Creswell, J. W. 1998, Qualitative Inquiry and Research Design: Choosing Among Five Tradition, London: SAGE Publications.

CNN Indonesia. (2014, 8 Desember), Hutan Adat direbut Negara, Warga Merana, https://www.cnnindonesia.com / nasional/20141218084758-20-18989/ hutan-adat-direbut-negara-wargamerana/ diakses pada 6 Oktober 2017.

Eko, S. (2005), Menggantang Asap?, Kritik dan Refleksi Atas gerakan Kembali ke Nagari, Yogyakarta: IRE.

Evers, Hans-Dieter. (1975), Changing Paterns of Minangkabau Urban Landownership, ANTHROPOLOGICA (17), pp. 86-110.

Firmansyah, N. (2016). Arus Babaliak ka Nagari: Antara Fakta Hibridasi Nagari dan Desa Adat, Makalah disampaikan dalam simposium Nasional Masyarakat Adat II di Universitas Pancasila 16-17 Mei 2016.

Hafidh, A., \& Krisdyatmiko. (2018). Akses Masyarakat Adat Terhadap Tanah Ulayat (Studi Kasus pada Masyarakat Adat Minangkabau di Nagari Bawan, Kabupaten Agam, Provinsi Sumatera Barat). Tesis, Universitas Gadjah Mada.

Harian Umum Singgalang. (2015, 11 April) Ninik Mamak dan Ratusan Warga Bawan Duduki Lahan PT AMP, http://hariansinggalang. co.id/ninik-mamak-dan-ratusan-wargabawan-duduki-lahan-pt-amp/ diakses pada 15 September 2017.

Hardiansyah. (2013). Teori Pengetahuan Edmund Husserl. Jurnal Substantia, 15(2), pp. 228-238.

Harsono, B. (2005), Hukum Agraria Indonesia: Sejarah Pembentukan Undang- Undang Pokok Agraria, Isi dan Pelaksanaannya, Jakarta: Djambatan.

Hukum Online (2011, 18 Agustus). Nasib Pengakuan Hak Nagari dalam Pengelolaan Sumber Daya Alam, http:// www.hukumonline.com / berita / nasib-pengakuan-hak-nagari-dalampengelolaan-sumber-daya-alam/ diakses pada 27 Oktober 2017.

Lanz, K., Gerber, J., \& Haller, T. (2018). Land Grabbing, the State and Chiefs: The Politics of Extending Commercial Agriculture in Ghana. Development and Change, 49(6), 1526-1552.

Lombard, M., \& Rakodi, C. (2016). Urban land conflict in the Global South: Towards an analytical framework. Urban studies, 53(13), 2683-2699.

Madjid, D.A. (1979). Mustika Adat Alam Minangkabau, Jakarta: Proyek Penerbitan Buku Bacaan dan Sastra Indonesia dan Daerah.

Manan, I. (1995). Birokrasi Modern dan Otoritas Tradisional di Minangkabau (Nagari dan Desa di Minangkabau), Padang: Yayasan Pengkajian Kebudayaan Minangkabau.

Melati, M. (2016), Kebijakan Pemerintah Daerah Kabupaten Biak Numfor Terhadap Perlindungan Hak Ulayat Laut, Tesis: Universitas Gadjah Mada.

Moleong, L. J. (2013). Metode Penelitian Kualitatif, Bandung: Remaja Rosdakarya.

Mulyana, D. (2001). Metode Penelitian Kualitatif, Bandung: Remaja Rosdakarya.

Muur, W. V. (2018). Forest conflicts and the informal nature of realizing indigenous land rights in Indonesia. Citizenship studies, 22(2), 160-174.

Michigan State University. (2006), A Guide to Interiew Guide, https://msu.edu/user/ mkennedy/digitaladvisor/Research/ interviewing.htm. diakses pada 11 November 2017.

Mongabay. (2016, 27 September). Sengketa Lahan di Batas Kelimutu: Antara Hak Adat dan Kawasan Konservasi, http:// www.mongabay.co.id/sengketa-lahandi-batas-kelimutu-antara-hak-adat-dankawasan-konservasi/ diakses pada 6 Oktober 2017.

Nasir, N. (2013), Kontinuitas Penguasaan Tanah Ulayat Masyarakat Adat Oleh Negara (Studi Kasus Penguasaan Tanah Ulayat Masyarakat Adat Kampung Naga Dari Masa Kolonial Belanda Hingga Era Reformasi, Tesis: Universitas Gadjah Mada.

Nasroen, M. (1971). Dasar Falsafah Adat Minangkabau, Jakarta: Bulan Bintang. 
Ribot, J. C dan Peluso, N. L. (2003), A Theory of Acces, The Rural Sociological Society Rural Sociology, 2(68). Pp. 153-181.

Salam, S. (2016), Kepastian Hukum Penerbitan Sertifikat Hak Komunal Sebagai Pelaksanaan Reforma Agraria, Jurnal Cita Hukum, 4(2). pp. 1-20.

Sari, N. (2010). Eksistensi Tanah Ulayat Masyarakat Minangkabau di Kecamatan Tanjung Emas Kabupaten Tanah Datar, Tesis. Yogyakarta: Universitas Gadjah Mada.

Siregar, B. B. dkk. (2002), Kembali ke Akar: Kembali ke Konsep Otonomi Masyarakat Asli, Jakarta: Forum Pengembangan Partisipasi Masyarakat.

Sugiyono. (2010). Memahami Penelitian Kualitatif, Bandung: Alfabeta.
Thontowi, J, dkk (2012), Aktualisasi Masyarakat Hukum Adat (MHA): Perspektif Hukum dan Keadilan Terakait Status MHA dan Hak-Hak Konstitusionalnya, Jakarta: Pusat Penelitian dan Pengkajian Perkara Mahkamah Konstitusi Republik Indonesia. Tuo, N. D. P. N. (1999), Tanah Ulayat Menurut Ajaran Adat Minangkabau, Padang: Yayasan Sakato Batuah LKAAM Sumatera Barat.

Yin K. R. (2011). Studi Kasus; Desain dan Metode, Jakarta: PT. Raja Grafindo Persada.

Zakaria, R Y. (1999), Kembalikan Kedaulatan Ulayat Masyarakat Adat, makalah

dipresentasikan pada "Kongres Masyarakat Adat Nusantara", Jakarta, 15-22 Maret 1999.

Zakaria, R Y. (2000). Abih Tandeh: Masyarakat Adat di Bawah Rejim Orde Baru. Jakarta: ELSAM. 